\title{
Analysis of the Predicament and Breakthrough of Teachers' Development in Local Colleges and Universities
}

\author{
Min Zheng', Qingqing Cai ${ }^{1}$ \\ ${ }^{1}$ Hubei University of Science and Technology Xiangning, China, 431700
}

Keywords: predicament; breakthrough; teachers' development; local colleges and universities

\begin{abstract}
In recent years, the rapid development of local colleges and universities, and the scale of universities has continued to expand. However, teachers of local college and universities face development difficulties, which restrict the growth of college education. Therefore, it is necessary to take measures to break through the predicament.
\end{abstract}

\section{Introduction}

In the development of colleges and universities, the construction of the teaching staff is the key, and the overall level and development effect of the teaching staff are the important contents of the assessment of colleges and universities. However, there are certain gaps in the situation of teachers in some local colleges and universities. The number of personnel and professional skills in the teaching staff do not meet corresponding standards. Therefore, the managers of local colleges and universities must pay attention to the promotion of the overall strength of the teaching staff, strengthen the comprehensive ability of teachers, and ensure that professional teachers have specialized skills. However, current local college teachers have exposed the development difficulties in their professional development. How to break through the development difficulties has become a problem that local colleges and universities need to solve in their development.

\section{Predicament in the Development of Local College Teachers}

\subsection{Development difficulties in teachers' teaching model}

The task of teaching in colleges and universities is to cultivate high-quality skilled talents for the society. In particular, local colleges and universities, many vocational colleges, so teachers will improve students' comprehensive skills as a teaching goal throughout the actual teaching. Many college teachers repeat the same teaching content in their work for a long period of time, and the same teaching methods are used for teaching students. Over time, this process-based teaching method lacks new ideas, teachers will gradually lose their direction of development, students will lose the initiative in the teaching of teachers lacking new ideas, and students will lack interest in explaining the teaching of professional teachers. In addition, many university teachers in addition to carrying out teaching tasks, there are many other work such as responsible for student management, to complete related research projects. And the accomplishment of these tasks is related to the performance of teachers. Therefore, the work intensity of university teachers is relatively large, and teachers do not have much time to develop themselves [1].

\subsection{The increasing difficulties of college teachers due to employment difficulty}

Due to the impact of the current teaching objectives of universities, in order to improve the employment rate of students after graduation, so graduates can be better developed in the society, higher requirements for professional courses teachers in colleges and universities. In the teaching methods of college professional course teachers, we should pay attention to the combination of professional theoretical knowledge and application ability. We must combine market demand for talents. Therefore, teaching methods must be more in line with the market's demand for talents and avoid college students' difficulties in adapting to market demands. Therefore, university teachers 
should pay attention to students' synchronous improvement in realizing theoretical knowledge and technical skills of students in teaching. Teaching needs to adopt a mixed model of theory and skills to avoid the disadvantageous situation of "re-theory and light skills" in teaching. However, in the actual professional course teaching process, teachers lack the corresponding professional skills and have no practical experience, which increases the difficulty of college teachers.

\subsection{Teachers' resilience influenced by continuous professional adjustment}

At present, in some local universities, in order to meet the needs of students to the greatest extent, the majors that are offered are often adjusted. In addition, due to the increasing demand for talents in society, colleges and universities also need to make corresponding adjustments to the profession in order to better adapt to the needs of social development, so that students can successfully find a job after graduation. However, colleges and universities will produce a lot of new majors when they adjust their majors accordingly. In the professional adjustment and the creation of a new professional, teachers need to constantly learn new professional knowledge otherwise they will be forced to change jobs, to perform administrative work or to manage students. However, no matter which method is adopted, it is unacceptable for college professional teachers who have been engaged in teaching for many years. Because of professional adjustments, professional teachers in universities need to relearn new knowledge, thus increasing teachers' professional difficulty. Especially for older teachers, learning new professional knowledge not only takes a long time, but also feels for age reasons. Some are not able to do it. From the point of view of professional research, college teachers have to achieve certain academic accomplishments for a certain field of professional knowledge, and must continue to study the profession. However, under the unfavorable conditions of professional adjustment, college teachers will affect the continuous research of teachers and will have an impact on their careers [2].

\subsection{Lack of professional training}

In the development of colleges and universities, due to the need for the training of skilled talents, the professional courses in colleges and universities introduce many new technologies and new technologies, but these technologies are mostly from the front lines of production and research. It is difficult to ensure the quality of "part-time teachers" from the society, and it is difficult for people to ensure stability. Due to the influence of various factors such as policies and treatment, professional and technical teachers in many universities can only be achieved through internal training. However, the internal training methods of many local universities are difficult to guarantee the effect. Due to the lack of an appropriate teacher professional evaluation system, teachers are not good at mastering new technologies and new processes. Some local colleges and universities lacked the necessary induction training for young teachers. Teachers' on-the-job training will be weakened due to college teaching pressure and economic conditions. Many local colleges and universities do not have institutional support for the development of teaching assistants. After simple training, they arrange young teachers to work in first-line teaching. In addition, local colleges and universities lack attention in training, and the relative independence of teachers and training teachers in classrooms affects the professional skills of teachers. Many teachers influence the further development due to the lack of professional training.

\subsection{Limited course development due to institutional deficiencies}

The improvement of the teaching level of teachers needs a supporting system to be achieved. Teachers must have a relaxed growth environment to achieve the improvement of teaching effectiveness. Many local college teachers are busy with daily teaching, and there is no time to study professional knowledge. It is difficult to achieve breakthroughs in teaching methods and curriculum development is limited. The teaching of teachers lacks the ability to be personalized, there is no teaching feature, and teaching is difficult to achieve art. College teachers are subjectively lacking the awareness of curriculum development and are not active in the development of professional courses. Although many teachers engage in a large number of teaching practices, they lack the corresponding teaching achievements. Due to lack of results, teachers have created 
obstacles for future development.

\subsection{The promotion of teachers due to professional title assessment system}

For local college teachers, upgrading the rank is an important part of the teacher's career. The rank promotion of college teachers is mainly achieved through professional titles. Titles are directly related to the income of college teachers. However, there are many obstacles in the evaluation of professional titles of local college teachers. Teachers need to have scientific research results, to publish papers, in order to achieve the requirements for job title assessment. However, due to the low level of school, local colleges and universities have many unfavorable conditions in scientific research conditions. There is a long way to go between research conditions and the application of scientific research topics and general universities. Therefore, there are many disadvantageous conditions for local college teachers to publish academic researches' in academic research. These conditions are an important part of the assessment of professional title of college teachers. Due to the nature of local schools, the development of college teachers is affected.

\section{Measures to Realize Professional Development for Local College Teachers}

\subsection{Strengthen advanced improvement}

An important reason for the predicament of professional development of local college teachers is that some college teachers are lack of enterprising consciousness and are overly immersed in the status quo. If they go on for a long time, the teaching ability of college teachers will be degraded and the teaching model will be backward. This situation is not conducive to teachers. The long-term development will also affect the learning effect of college students. Therefore, we must take various measures to improve the overall quality of college teachers, create conditions for further development for teachers, so that teachers can get more opportunities for development, you can get in touch with the most advanced technology, the most cutting-edge teaching ideas, in order to facilitate the innovation of teaching models. Under the conditions permitting, local colleges and universities can adopt academic exchanges so that more college teachers can have access to advanced educational concepts. Through exchanges, they can learn from the teaching models of advanced universities and contribute to the realization of the original teaching methods. The improvement removes the influence of the original teaching model. In addition, individual college teachers should pay attention to the study of new knowledge in the professional field, keep the teaching content fresh, and also help improve students' sense of innovation.

\subsection{Pay attention to communication with students}

In the current local college education, students do not cooperate with the teachers' teaching work. This phenomenon will affect the improvement of teaching results, and will also cause the predicament of college teachers' career development. Therefore, in order to realize the professional development of college teachers, teachers and students must communicate more. Professional teachers in colleges and universities should listen more to the opinions of students and encourage students to express their true ideas. On this basis, college teachers should actively reform the drawbacks of the original teaching model. In addition, university teachers should base themselves on the training of students' abilities and constantly summarize teaching methods in teaching practice to form teaching topics [3].

\subsection{Social support for college teachers}

In order to ensure that college teachers have a good career development, all levels of society should give full respect to college teachers to help colleges and universities create a way out. The first is that local governments should pay attention to the development of local colleges and universities, take necessary policies to support the development of colleges and universities, and establish public opinion guides that are conducive to the development of college teachers, correctly view the role of college teachers, and guide university teachers in teaching through the necessary incentive mechanisms. The government must also introduce supporting policies to increase funding 
for local colleges and universities to ensure the sound development of universities and colleges, and lay stress on creating conditions for the teaching work of university teachers. Local governments should pay attention to the career development of college teachers. They can learn from the experience of teacher management in advanced universities and establish a system of teacher performance evaluation that is consistent with the actual situation of local colleges and universities, giving university teachers more opportunities for development. The competent government departments and colleges and universities must also improve the scientific research management system, provide necessary support to the scientific research work of college teachers, and pay attention to improving the professional qualities of college teachers, so as to create conditions for university teachers' scientific research work.

\subsection{Keep pace with the times and take the initiative}

Many college teachers are busy with their daily work and their work is relatively trivial. Many teachers are busy with lesson preparation and classes every day. They also need to complete homework corrections, do a good job of the students' ideological work, and handle the affairs of the class they are taking. If teachers are personally lacking in goals, they have no way to progress. Consciousness, there is no positive personal development concept as the direction of action, there will be a lack of sense of responsibility, and it will create occupational burnout throughout the busy day. Therefore, colleges and universities must have a sense of responsibility. Once they have responsibilities, they will notice their own actions and will strictly demand themselves. College teachers should use the vocational functions of evangelism to increase their sense of social responsibility and personal mission, and constantly explore new ways of teaching and educating people. As the teaching system, content, methods and means of colleges and universities have undergone great changes, the ideological characteristics of undergraduates are constantly changing. Therefore, teachers' teaching ideas and teaching methods must be constantly updated, and they must keep pace with the development of the times.

\subsection{Create an environment conducive to teacher development}

In the management of universities, colleges and universities pay attention to creating an environment conducive to the development of education. We must widely listen to the opinions and suggestions of front-line faculty and staff through various forms such as the Workers' Congress and exchanges to ensure the democracy and science of school decision-making. Schools should pay attention to maintaining teachers. Schools should focus on the long-term development of teachers, pay attention to the professional skills of teachers, and strive to create a space conducive to the development of teachers so that teachers can feel humane care in a harmonious atmosphere and have more time to complete their teaching tasks. Improve teaching effectiveness.

\subsection{Pay attention to human resources management}

With the rapid development of society and the development of society in transition, local colleges and universities must maintain their advantages in competition and must attach great importance to the management of human resources. For the disadvantages in the development of college education, boldly carry out reforms and innovations. Human resource management should be an important part of university management. In the face of market competition, colleges and universities must change the original management methods and implement innovations in human resources management. Colleges and universities should use the manpower of the school as a source of development. Human resources management should have a sense of innovation. This is also a necessary choice for the development of the times. It is necessary to change the human resource management model that is not conducive to the development of college teachers and create conditions for the development of outstanding talents. With talents as a guarantee, colleges and universities will have competition. In addition, by innovating the human resources management system, it is necessary to provide teachers with more training opportunities, which can effectively improve the technical level of teachers, stabilize the teaching staff in universities, increase teachers' sense of responsibility, and inspire the work enthusiasm of university teachers. 
For the use of human resources, the human resources management department must combine the characteristics of the positions and the skills of the personnel to carry out effective and rational deployment. The most suitable personnel should be placed in the most suitable position and the role of talents should be fully utilized. Through improving the incentive mechanism and adopting diversified incentive methods, high-level talents can play a greater role [4].

\section{Conclusion}

Local college teachers face many difficulties in their development and need to break through. The construction of college teachers is related to the future development of colleges and universities. Therefore, attention is paid to various aspects. In particular, university administrators must take effective measures to enhance teachers' comprehensive ability and create conditions for the development of teachers. It is also conducive to the development of colleges and universities.

\section{Acknowledgements}

Fund Project: School-level Education Reform Project "The Path of Teachers' Growth in the Context of Local Colleges and Universities" Project Number Xnsk-X1178.

\section{References}

[1] Fang Yihua. Problems and countermeasures for the career development of teachers in higher vocational colleges[J]. Adult Education, 2016(11):49-50

[2] Liu Faxiang. Thoughts on the Career Management of Teachers in Higher Vocational Colleges in the New Era[J]. Education and Occupation, 2016(8):145-146

[3] Tian Zengwei. The Idea of Building "Double-qualified" Teachers in Higher Vocational Colleges Based on Cooperation between School and Enterprise[J]. Vocational and Technical Education, 2015, (9): 159-161

[4] Liu Wenjuan. Research on Evaluation Method of Teachers' Performance in Higher Vocational Colleges Based on Fuzzy Comprehensive Evaluation[J]. Wireless Network Technology, 2016(8):103-104 